\title{
Study of seasonal incidence and impact of abiotic factors on sucking pests of brinjal
}

\author{
Shaik Javed", K. Vijaya Lakshmi, C. Narendra Reddy, B. Vidya Sagar and M. Shanthi \\ Department of Entomology, College of Agriculture, Professor Jayashankar Telangana State Agricultural \\ University, Rajendranagar, Hyderabad -500030 (Telangana), INDIA \\ ${ }^{*}$ Corresponding author. E-mail: skjaved789@gmail.com \\ Received: April 7, 2016; Revised received: November 2, 2016; Accepted: January 6, 2017
}

\begin{abstract}
The present investigation was undertaken to find the impact of abiotic factors on seasonal incidence and sucking pest complex of brinjal under field conditions during kharif 2015-2016. The incidence of leaf hopper population $\left(2.80 \mathrm{Lh} / \mathrm{L}\right.$ i.e., Leaf hopper mean population/leaf) was noticed during $34^{\text {th }}$ standard week and reached peak by $40^{\text {th }}$ standard week $(5.00 \mathrm{Lh} / \mathrm{L})\left(\right.$ October) whereas the aphid population was noticed during the $34^{\text {th }}$ standard week $(3.00 \mathrm{Lh} / \mathrm{L})$ and peak population observed during the $40^{\mathrm{th}}$ standard week $(4.60 \mathrm{Lh} / \mathrm{L})$ (October). Correlation studies showed that among the various abiotic factors, maximum temperature showed highly significant positive correlation $(r=0.77)$ and sunshine hours $(r=0.61)$ showed significant positive correlation with the leaf hopper population. In case of aphid population, maximum temperature showed significant positive correlation $(r=0.70)$, rainfall showed highly significant negative correlation $(r=-0.74)$ and relative humidity evening $(r=-0.59)$ showed significant negative correlation with aphid population. The present investigations will give a brief idea about how the abiotic factors influencing the sucking pests of brinjal.
\end{abstract}

Keywords: Abiotic factors, Aphids, Brinjal, Leaf hoppers

\section{INTRODUCTION}

Brinjal, Solanum melongena L. is one of the most important vegetables in South Asia which accounts for almost fifty percent of the world's area under cultivation. (Alam et al., 2003). In India, brinjal is an important commercial vegetable crop grown throughout the year over the country (Pareet, 2009). Due to its versatility in use in Indian food, brinjal is often described as the 'King of vegetables' (Choudhary and Gaur, 2009). Based on its highest production potential and availability of the produce to consumers, it is also termed as common man's vegetable. In India brinjal is cultivated over an area of 711.3 thousand hectares with an annual production of 13557.8 thousand MT and productivity of $19.1 \mathrm{MT} / \mathrm{ha}$.

In the brinjal field, various pests prevail during seedling to harvesting stage and the loss caused by brinjal pests vary from season to season depending upon environmental factors (Anjali et al., 2012). The crop was attacked by number of sucking pests during vegetative stage. Among the sucking pests, leaf hopper (Amrasca biguttula biguttula Ishida), Aphid (Aphis gossypii Glover) and whitefly (Bemisia tabaci Gennaus) cause significant damage during vegetative stage. Sucking pests are highly governed by various abiotic factors and meteorological parameters play a pivotal role in the biology of sucking pest. Temperature, relative humidity, rainfall, wind speed, evaporation and sunshine hours weather parameters that directly influence the activity of a given species of insect. Hence, it is necessary to have a thorough knowledge on seasonal incidence of different sucking pests with respect to abiotic factors, which helps in developing pest prediction models for forecasting pest incidence. The investigation was therefore, undertaken to find out the impact of the weather factors on the incidence of pest complex of brinjal.

\section{MATERIALS AND METHODS}

The experiment was carried out under field conditions at the College Farm, College of Agriculture, Professor Jayashankar Telangana State Agricultural University (PJTSAU), Rajendranagar, Hyderabad on brinjal locally popular variety, Shyamla during Kharif 2015-16. For sowing the seed, nursery bed was prepared to fine tilth and raised to about $15 \mathrm{~cm}$ height with $1 \mathrm{~m}$ width and convenient length. Seeds were sown during first week of July 2015 about $6 \mathrm{~cm}$ apart between the lines and covered with fine soil and watered regularly. The transplanting of seedlings was done during the first week of August. One month old seedlings were transplanted at two seedlings per hill in a bulk plot of 600 $\mathrm{m}^{2}$ by adopting $75 \mathrm{~cm} \times 60 \mathrm{~cm}$ spacing. The experimental field was divided into three blocks and each block was considered as a replication. All recommended agronomical practices were followed from time to time to raise the crop successfully. 
The data were recorded on pest population in the field at weekly interval (Standard Week) from the initiation of the pest infestation and was continued up to crop maturity. A total of 5 plants from each replication were selected and tagged for recording the observations on sucking pests. The population of both nymphs and adults of leaf hopper and aphids were counted during early morning hours on 3 leaves (each from top, middle and bottom canopy) from each of the 5 selected and tagged plants. Weekly data on different abiotic factors was also recorded. Data so obtained was then subjected to statistical analysis for correlation, test of significance and step down multiple linear regression. Combined effect of weather parameters on pest populations were identifies by using the Multiple Linear Regression Step Down analysis. The following formulae were used to express the effect of weather parameters on pest populations.
$\mathrm{Y}=\mathrm{a}+\mathrm{bx}_{1}+\mathrm{bx}_{2}+\ldots . . \mathrm{bx} \mathrm{x}_{\mathrm{n}}$

\section{RESULTS AND DISCUSSION}

The observations recorded on the different sucking pests viz. leaf hopper and aphids during kharif 2015-16 were presented in the table 1 . Indicated that initial incidence was observed two weeks after transplanting. Though the leaf hopper population recorded up to $45^{\text {th }}$ standard week, it was found declining further from (4.60 leaf hoppers/leaf) $41^{\text {st }}$ standard week to 2.40 leaf hoppers/ leaf by $45^{\text {th }}$ standard week. Lowest leaf hopper population (1.40 leaf hoppers /leaf) were recorded during the $38^{\text {th }}$ standard week.

Correlation studies were carried out to find out the effect of abiotic factors on the leaf hopper population. The results (Table.3, figs.1, 2) indicated that leaf hopper population has highly significant and positive correlation with the maximum temperature $(\mathrm{r}=0.77)$, sig-

Table 1. Incidence of leaf hopper population in brinjal influenced by weather parameters for five plants/replication.

\begin{tabular}{|c|c|c|c|c|c|c|c|c|c|c|}
\hline \multirow{2}{*}{$\begin{array}{l}\text { Standard } \\
\text { weeks }\end{array}$} & \multirow{2}{*}{$\begin{array}{c}\text { Dates of } \\
\text { standard } \\
\text { weeks }\end{array}$} & \multirow{2}{*}{$\begin{array}{l}\text { Leaf hop- } \\
\text { per mean } \\
\text { popula- } \\
\text { tion/leaf }\end{array}$} & \multicolumn{2}{|c|}{ Temperature } & \multicolumn{2}{|c|}{$\begin{array}{c}\text { Relative } \\
\text { humidity }\end{array}$} & \multirow[t]{2}{*}{$\begin{array}{c}\text { Rainfall } \\
\text { (mm) }\end{array}$} & \multirow{2}{*}{$\begin{array}{c}\text { Wind } \\
\text { speed } \\
(\mathbf{k m} / \mathbf{h r})\end{array}$} & \multirow{2}{*}{$\begin{array}{l}\text { Sun- } \\
\text { shine } \\
\text { (hrs.) }\end{array}$} & \multirow{2}{*}{$\begin{array}{c}\text { Evapo- } \\
\text { ration } \\
(\mathrm{mm})\end{array}$} \\
\hline & & & $\begin{array}{l}\text { Max. } \\
\left({ }^{\circ} \mathrm{C}\right)\end{array}$ & $\begin{array}{l}\text { Min. } \\
\left({ }^{\circ} \mathrm{C}\right)\end{array}$ & $\begin{array}{c}\text { I } \\
(\%)\end{array}$ & $\begin{array}{c}\text { II } \\
(\%)\end{array}$ & & & & \\
\hline 34 & Agu.20-26 & 2.80 & 30.43 & 22.43 & 89.71 & 69.00 & 4.29 & 3.66 & 3.66 & 3.53 \\
\hline 35 & Aug.27-sep.02 & 3.80 & 31.50 & 22.71 & 90.57 & 64.57 & 7.06 & 3.29 & 6.63 & 5.37 \\
\hline 36 & Sept.03-09 & 2.60 & 30.07 & 22.14 & 83.29 & 66.71 & 4.09 & 3.63 & 3.90 & 5.17 \\
\hline 37 & Sept.10-16 & 4.80 & 33.43 & 22.93 & 88.43 & 59.14 & 4.40 & 1.41 & 7.17 & 5.56 \\
\hline 38 & Sept.17-23 & 1.40 & 28.36 & 21.93 & 95.86 & 85.71 & 13.14 & 0.80 & 1.67 & 2.50 \\
\hline 39 & Sept.24-30 & 3.20 & 30.43 & 22.21 & 89.57 & 61.00 & 6.20 & 1.21 & 4.43 & 3.51 \\
\hline 40 & Oct.01-07 & 5.00 & 31.93 & 22.29 & 89.43 & 57.57 & 0.29 & 0.20 & 7.16 & 4.33 \\
\hline 41 & Oct.08-14 & 4.60 & 31.36 & 21.14 & 96.00 & 55.00 & 4.94 & 0.20 & 5.84 & 3.43 \\
\hline 42 & Oct.15-21 & 4.20 & 33.36 & 19.57 & 88.43 & 37.43 & 0.00 & 0.13 & 7.89 & 4.50 \\
\hline 43 & Oct.22-28 & 3.80 & 32.79 & 19.14 & 91.71 & 42.00 & 0.00 & 0.61 & 8.36 & 4.47 \\
\hline 44 & Oct.29-Nov.04 & 3.20 & 32.43 & 18.14 & 89.29 & 43.57 & 0.00 & 1.80 & 8.94 & 4.69 \\
\hline 45 & Nov.05-11 & 2.40 & 31.29 & 20.71 & 91.71 & 50.86 & 2.61 & 1.34 & 7.33 & 3.57 \\
\hline
\end{tabular}

Table 2. Incidence of aphid population in brinjal influenced by weather parameters for five plants/replication.

\begin{tabular}{|c|c|c|c|c|c|c|c|c|c|c|}
\hline \multirow{2}{*}{$\begin{array}{l}\text { Standard } \\
\text { weeks }\end{array}$} & \multirow[t]{2}{*}{$\begin{array}{l}\text { Dates of stand- } \\
\text { ard weeks }\end{array}$} & \multirow{2}{*}{$\begin{array}{l}\text { Aphid } \\
\text { popula- } \\
\text { tion/leaf }\end{array}$} & \multicolumn{2}{|c|}{ Temperature } & \multicolumn{2}{|c|}{$\begin{array}{c}\text { Relative } \\
\text { humidity }\end{array}$} & \multirow[t]{2}{*}{$\begin{array}{l}\text { Rainfall } \\
\text { (mm) }\end{array}$} & \multirow{2}{*}{$\begin{array}{c}\text { wind } \\
\text { speed } \\
(\mathrm{km} / \mathrm{hr})\end{array}$} & \multirow{2}{*}{$\begin{array}{l}\text { Sun- } \\
\text { shine } \\
\text { (hrs.) }\end{array}$} & \multirow{2}{*}{$\begin{array}{c}\text { Evapo- } \\
\text { ration } \\
(\mathrm{mm})\end{array}$} \\
\hline & & & $\begin{array}{l}\text { Max. } \\
\left({ }^{\circ} \mathrm{C}\right)\end{array}$ & $\begin{array}{l}\text { Min. } \\
\left({ }^{\circ} \mathrm{C}\right)\end{array}$ & I (\%) & $\begin{array}{c}\text { II } \\
(\%)\end{array}$ & & & & \\
\hline 34 & Agu.20-26 & 3.00 & 30.43 & 22.43 & 89.71 & 69.00 & 4.29 & 3.66 & 3.66 & 3.53 \\
\hline 35 & Aug.27-sep.02 & 2.60 & 31.50 & 22.71 & 90.57 & 64.57 & 7.06 & 3.29 & 6.63 & 5.37 \\
\hline 36 & Sept.03-09 & 2.80 & 30.07 & 22.14 & 83.29 & 66.71 & 4.09 & 3.63 & 3.90 & 5.17 \\
\hline 37 & Sept.10-16 & 3.40 & 33.43 & 22.93 & 88.43 & 59.14 & 4.40 & 1.41 & 7.17 & 5.56 \\
\hline 38 & Sept.17-23 & 0.80 & 28.36 & 21.93 & 95.86 & 85.71 & 13.14 & 0.80 & 1.67 & 2.50 \\
\hline 39 & Sept.24-30 & 3.00 & 30.43 & 22.21 & 89.57 & 61.00 & 6.20 & 1.21 & 4.43 & 3.51 \\
\hline 40 & Oct.01-07 & 4.60 & 31.93 & 22.29 & 89.43 & 57.57 & 0.29 & 0.20 & 7.16 & 4.33 \\
\hline 41 & Oct.08-14 & 3.40 & 31.36 & 21.14 & 96.00 & 55.00 & 4.94 & 0.20 & 5.84 & 3.43 \\
\hline 42 & Oct.15-21 & 4.00 & 33.36 & 19.57 & 88.43 & 37.43 & 0.00 & 0.13 & 7.89 & 4.50 \\
\hline 43 & Oct.22-28 & 3.60 & 32.79 & 19.14 & 91.71 & 42.00 & 0.00 & 0.61 & 8.36 & 4.47 \\
\hline 44 & Oct.29-Nov.04 & 2.80 & 32.43 & 18.14 & 89.29 & 43.57 & 0.00 & 1.80 & 8.94 & 4.69 \\
\hline 45 & Nov.05-11 & 1.80 & 31.29 & 20.71 & 91.71 & 50.86 & 2.61 & 1.34 & 7.33 & 3.57 \\
\hline
\end{tabular}

Table 3. Correlation coefficient studies correlated between sucking pests of brinjal and weather parameters.

\begin{tabular}{|c|c|c|c|c|c|c|c|c|}
\hline \multirow[b]{2}{*}{$\begin{array}{l}\text { Insect pest of } \\
\text { brinjal }\end{array}$} & \multicolumn{2}{|c|}{ Temperature } & \multicolumn{2}{|c|}{ Relative humidity } & \multirow{2}{*}{$\begin{array}{l}\text { Rainfall } \\
(\mathrm{mm})\end{array}$} & \multirow{2}{*}{$\begin{array}{l}\text { Wind } \\
\text { speed } \\
(\mathbf{k m} / \mathbf{h r} .)\end{array}$} & \multirow{2}{*}{$\begin{array}{l}\text { Sunshine } \\
\text { hours } \\
\text { (hrs.) }\end{array}$} & \multirow{2}{*}{$\begin{array}{l}\text { Evaporation } \\
(\mathrm{mm})\end{array}$} \\
\hline & $\begin{array}{l}\text { Max. } \\
\left({ }^{\circ} \mathrm{C}\right)\end{array}$ & $\begin{array}{l}\text { Min. } \\
\left({ }^{\circ} \mathrm{C}\right)\end{array}$ & $\begin{array}{l}\text { I } \\
(\%)\end{array}$ & $\begin{array}{l}\text { II } \\
(\%)\end{array}$ & & & & \\
\hline Leafhopper & $0.77 * *$ & 0.02 & -0.10 & -0.52 & -0.53 & -0.38 & $0.61 *$ & 0.51 \\
\hline Aphid & $0.70 *$ & 0.09 & -0.36 & $-0.59 *$ & $-0.74 * *$ & -0.28 & 0.54 & 0.46 \\
\hline
\end{tabular}




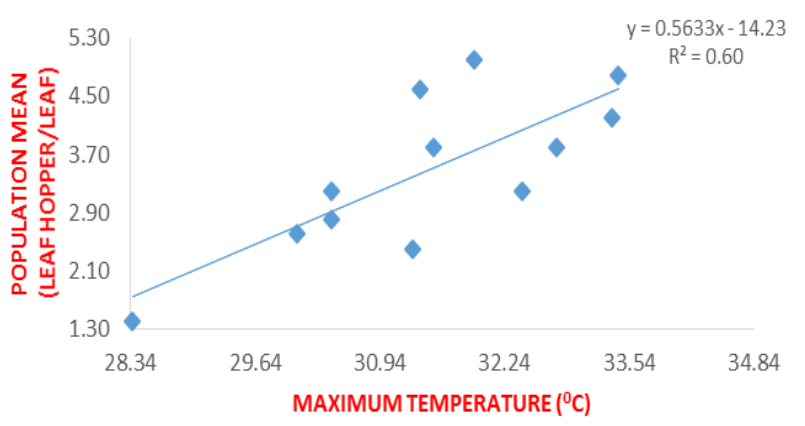

Fig.1. linear regression equation between leaf hopper population and maximum temperature in brinjal.

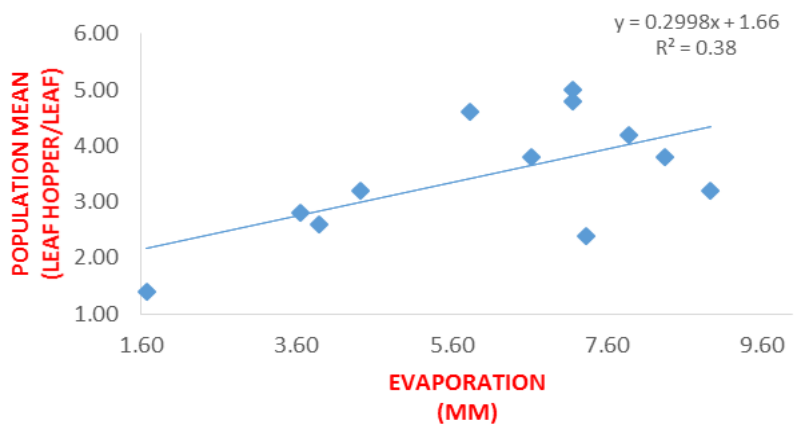

Fig.2. linear regression equation between leaf hopper population and evaporation in brinjal.

nificant and positive correlation with the sunshine hours $(r=0.61)$. Relative humidity I $(r=-0.10)$, relative humidity II $(\mathrm{r}=-0.52)$, rainfall $(\mathrm{r}=-0.53)$ and wind speed $(\mathrm{r}=-0.38)$ are showed negative but nonsignificant correlation with leaf hopper population, whereas minimum temperature $(\mathrm{r}=0.02)$ and evaporation $(\mathrm{r}=0.51)$ are showed non-significant positive correlation with leaf hopper population. The present observations are in confirmation with findings of Tiwari et al. (2011) where they found that maximum temperature $(0.7241)$, minimum temperature $(0.6912)$, sunshine hours $(0.130)$ showed significant positive correlation with the leaf hopper population Amrasca bigutulla bigutulla. Similar results were obtained by Naik et al. (2009) and Meena et al. (2010) they found that the association of leaf hopper population was positive and non-significant with rainfall during 2010-11, while, it was negative and significant during 2011-12. The results of the correlation values were in close agreement with the results of Omprakash et al. (2013) where the maximum temperature $(0.373)$, minimum temperature $(0.214)$ were positively correlated ; whereas rainfall $(-0.483)$, relative humidity I $(-0.421)$, relative humidity II (-0.228) were negatively correlated. The similar results were also reported by Patel et al. (2015). In their findings also, the correlation values for maximum temperature $(0.5570)$, minimum temperature $(0.3183)$ and wind velocity $(0.1748 \mathrm{~km} / \mathrm{hr}$.) have shown positive correlation with leaf hopper population, whereas relative humidity I $(-0.1621)$, relative humidity II $(-0.0593)$ and rainfall $(-0.3746)$ showed the nega-

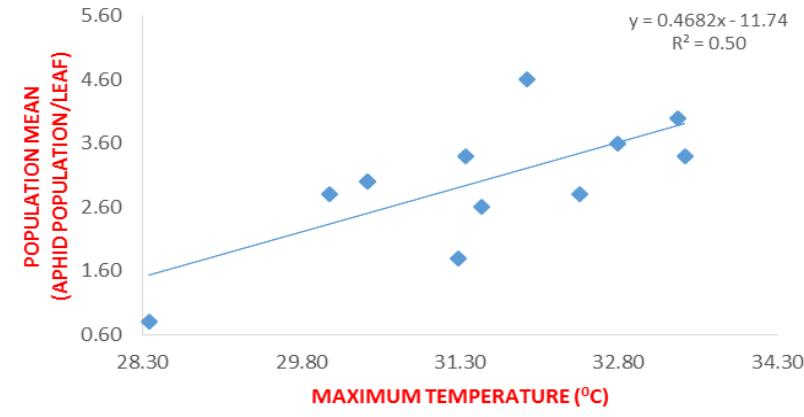

Fig.3. linear regression equation between aphid population and maximum temperature in brinjal.

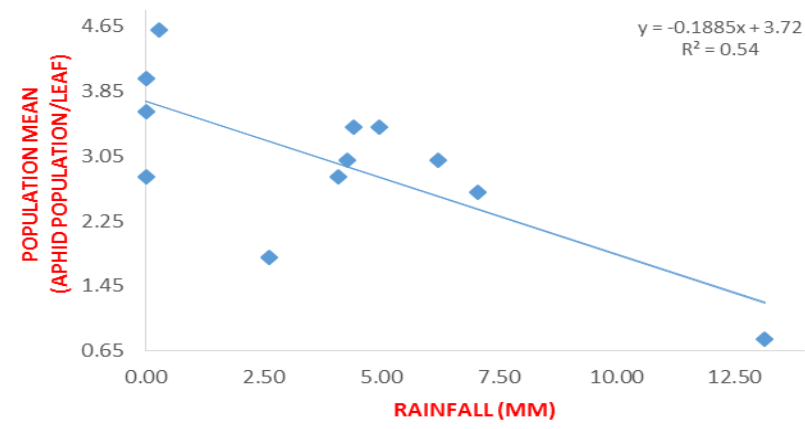

Fig.4. linear regression equation between aphid population and rainfall in brinjal.

tive correlation.

To find out the combined effect of weather parameters on leaf hopper populations for that Multiple Linear Regression Step Down analysis was carried out. Among all the parameters minimum temperature, $\mathrm{RH}$ I, rainfall, wind speed and evaporation showed 77 per cent impact on the leaf hopper population.

$\mathrm{Y}=-23.34+0.45^{*}$ minimum temperature $+0.16^{*} \mathrm{RH}-\mathrm{I}$ $-0.21^{*}$ rainfall $-0.35^{*}$ wind speed $+0.78^{*}$ evaporation $\left(\mathrm{R}^{2}=0.77\right)$

The incidence of Aphis gossypii nymphs and adults population was observed during crop growing period kharif 2015-16 are presented in the table 2. Initial incidence was observed two weeks after transplanting. Though the aphid population recorded up to $45^{\text {th }}$ standard week (1.80 aphids/leaf), it was found declining further from $43^{\text {rd }}$ standard week i.e., 3.60 to 1.80 aphids/leaf by $45^{\text {th }}$ standard week. Lowest aphid population ( 0.80 aphids/leaf) were recorded during the $38^{\text {th }}$ standard week.

To find out the effect of abiotic factors on the aphids population can be done by using the Correlation studies. The results (Table.3, figs.3\&4) indicated that aphid population has highly significant and positive correlation with the maximum temperature $(r=0.70)$, highly significant and negative correlation with the rainfall ( $\mathrm{r}$ $=-0.74$ ) and significant with negative correlation was showed by Relative humidity II $(\mathrm{r}=-0.59)$. Relative humidity I $(r=-0.36)$ and wind speed $(r=-0.28)$ showed non-significant negative correlation, whereas minimum temperature $(\mathrm{r}=0.09)$, sunshine hours $(\mathrm{r}=$ 
$0.54)$ and evaporation ( $\mathrm{r}=0.46)$ showed nonsignificant positive correlation with aphid population. The correlation values of the present experiment were in close agreement with the findings of Patel et al. (2015) where the correlation values for maximum temperature (0.6070), minimum temperature (0.2909) and wind velocity $(0.1548 \mathrm{~km} / \mathrm{hr}$.) have shown positive correlation with aphid population, and relative humidity I $(-0.2160)$, relative humidity II $(-0.1207)$, rainfall ($0.3961)$ showed the negative correlation.

Multiple Linear Regression Step Down analysis was carried out to find out the combined effect of weather parameters on aphid population. Among all the parameters minimum temperature, rainfall, wind speed, sunshine hours and evaporation showed 68 per cent impact on the aphid population.

$\mathrm{Y}=-1.76+0.27 *$ minimum temperature $-0.28 *$ rainfall $-0.37 *$ wind speed $-0.20 *$ sunshine hours $+0.40^{*}$ evaporation $\left(\mathrm{R}^{2}=0.68\right)$

\section{Conclusion}

The present experiment provides an insight on population dynamics of insect pests of brinjal. It can be concluded that seasonal population fluctuation of major insect pests on brinjal crop is greatly influenced by abiotic factors and peak population levels were observed during September to October. Leaf hopper population (2.80) was noticed during $34^{\text {th }}$ standard week and reached peak by $40^{\text {th }}$ standard week (5.00) (October) whereas the aphid population was noticed during the $34^{\text {th }}$ standard week (3.00) and peak population observed during the $40^{\text {th }}$ standard week (4.60) (October). The statistically significant values indicated that occurrence of insect pests population were due to the prevailing ecological conditions. The management of brinjal pest complex during kharif sown brinjal under tropical and semi tropical zones should therefore be promoted and tailored from July/August onwards using integrated approaches.

\section{ACKNOWLEDGEMENTS}

The researcher's team is sincerely thankful to the Professor Jayashankar Telangana State Agricultural University for providing research facilities. We also thank UGC for providing financial assistance through Award of Maulana Abul Kalam Azad National Fellowship (MANF) during the research.

\section{REFERENCES}

Alam, S. N., Rashid, M. A., Rouf, F. M. A., Jhala, R. C. and Patel, J. R. (2003). Development of an integrated pest management strategy for eggplant fruit and shoot borer in South Asia, Tech. Bull. AVRDC, pp. 28.

Anjali, M., Singh, N. P., Mahesh, M. and Swaroop, S. (2012). Seasonal incidence and effect of abiotic factors on population dynamics of major insect pests on brinjal crop. J. Environ. Res. Develop., 7(1): 431-435

Choudhary, B. and Gaur, K. (2009). The development and regulation of Bt. Brinjal in India (Eggplant/Aubergine). ISAAA. Brief No. 38

Meena, N. K., Kanwat, P. M., Meena, A. and Sharma, J. K. (2010). Seasonal incidence of jassids and whiteflies on okra, Abelmoschus esculentus (L.) Moench in semi-arid region of Rajastan. Annals of Agri Bio Research, 15(1): 25-29

Naik, C. B., Rao, V. A., Krishnayya, P. V. and Chalam, M.S.V. (2009). Seasonal incidence and management of Bemisia tabaci and Amrasca biguttula biguttula of brinjal. Ann. Pl. Protec. Sci., 17: 9-13

Omprakash, S., Raju, S. V. S. and Rajkumar, B. V. (2013). Influence of abiotic and biotic factors on the seasonal incidence of major sucking pests of brinjal. Journal of Progressive Agriculture, 4(2): 87-90

Pareet, J. D. and Basavanagoud, K. (2009). Evaluation of bio -pesticides against brinjal shoot and fruit borer and sucking pests. Annals of Plant Protection Sciences, 17 (2):463-464

Patel, H. V., Radadia, G. G. and Chavda, S. K. (2015). Seasonal incidence of major insect pests of brinjal crop during summer season. Insect Environment, 20(4):149-151 